Egyptian Journal of Aquatic Biology \& Fisheries

Zoology Department, Faculty of Science,

Ain Shams University, Cairo, Egypt.

ISSN $1110-6131$

Vol. 25(6): 513 - 527 (2021)

www.ejabf.journals.ekb.eg

\title{
Effects of Feeding Frequency on Growth Performance of the Juvenile Bagrid Catfish, Chrysichthys nigrodigitatus
}

\section{Christian Larbi Ayisi ${ }^{1 *}$, Grace Debra ${ }^{2}$, Elliot Haruna Alhassan ${ }^{2}$}

1-Department of Water Resources and Sustainable Development, School of Sustainable Development, University of Environment and Sustainable Development, Somanya, Ghana

2-Department of Fisheries \& Aquatic Resources Management, University for Development Studies, P. O. Box TL 1882, Tamale - Ghana

*Corresponding Author: aclarbi@uesd.edu.gh

\section{ARTICLE INFO}

\section{Article History:}

Received: Jan. 19, 2021

Accepted: Apr. 13, 2021

Online: Dec. 30, 2021

Keywords:

Proximate composition,

Water Quality,

Feed conversion ratio,

Feed utilization.

\section{ABSTRACT}

This study was presented to evaluate the effects of feeding frequency on growth performance, feed utilization, proximate composition and water quality parameters of the Bagrid catfish (Chrysichthys nigrodigitatus). Four groups of fishes were fed at four different feeding frequencies; once, twice, thrice and four times per day (Trt1, Trt2, Trt3\& Trt4, respectively).. C. nigrodigitatus, with an initial weight of $24.80 \pm 0.99 \mathrm{~g}$, were stocked at 30 fishes per concrete tanks, with dimensions of $3 \mathrm{~m} \times 1 \mathrm{~m} \times 1 \mathrm{~m}$ and fed to apparent satiation in accordance to the designated feeding frequencies. Fish fed Trt2 recorded ammonia content of $0.26 \pm 0.04$ and was significantly lower than fish fed $\operatorname{Trt} 4 \quad(\mathrm{P}<0.05)$. However, no significant difference was detected in values of temperature, $\mathrm{pH}$, nitrite and nitrate. The maximum final weight $(67.20 \pm 2.07)$ and specific growth rate $(4.13 \pm 0.03)$ were observed in fish fed $\operatorname{Trt} 2$ and were significantly higher than all other groups $(\mathrm{P}<0.05)$. A significant difference was recorded among treatments with respect to protein efficiency ratio, feed intake and feed conversion ratio. Protein efficiency ratio was higher in fish fed Trt $2(1.72 \pm$ $0.08)$ and was significantly higher than fish fed $\operatorname{Trt} 3(0.87 \pm 0.06)$ and $\operatorname{Trt} 4$ $(0.92 \pm 0.06)$. Fish fed Trt2 consumed more feed $(42.01 \pm 4.17)$ and was significantly higher than all other groups. In conclusion, the optimum feeding frequency of Bagrid catfish (Chrysichthys nigrodigitatus) was proved to be two times a day with equal intervals.

\section{INTRODUCTION}

Feed is remarkably the highest costing variable in aquaculture facilities. Understanding the nutrient requirements and implementing the appropriate feeding strategies can reduce waste and increase profits. Feed efficiency is vital in livestock farming in general and in aquaculture, in particular (Ali et al., 2016).

Economic profitability and competitiveness of the production sectors depend to a great extent on the adequacy of the feeding activities during the grow-out phase (Dias $\boldsymbol{e t}$ al., 2011). Feed management, in terms of optimization (feeding rate and frequency), has 
become a crucial point of study in the culture of many aquaculture species (Tiamiyu $\boldsymbol{e t}$ al., 2018). A proper feeding practice involves providing a cost-effective foodstuff at the right time(s), with proper amounts and in the proper form for the optimal fish growth.

Studies on feeding rate, frequency, feed intake and the ability to absorb nutrients can have a significant impact on fish welfare and growth (Tian et al., 2015). Feeding frequency should be prioritized since it has effects on both the growth and the survival of fish during their early life stages (Villarroel et al., 2011). Given the optimal feeding frequency, fish growth rate would increase due to the feed intake improvement related to the gastric evacuation that enhances fish appetite (Riche et al., 2014). Additionally, nutrient utilization in feed is influenced by feeding frequency (Silva et al., 2007).

Both over- and underfeeding can be detrimental to the production of fish. Lower feeding frequency does not only reduce fish growth but also lower their survival rate. Higher feeding frequency, on the other hand, raises cost of breeding fish, and increases the accumulation of waste, which negatively affects water quality (decrease dissolved oxygen and increase ammonia content) (Tian et al., 2015). In addition, over feeding increases susceptibility to infections (due to increased susceptibility to infectious disease by stress through poor water quality) (Ng et al., 2000; Dwyer et al., 2002).

Some studies have been conducted on the effects of feeding frequency on growth, feed utilization and immune response in several freshwater fishes, including: Clarias gariepinus (Okeke et al., 2016; Okomoda et al., 2019) and the Nile tilapia (Alemayehu \& Getahun, 2017; Thongprajukaew et al., 2017). Up till now, no study has addressed the effects of feeding frequency on growth, feed utilization and proximate composition of Bagrid catfish. Thus, to fill this gap in literature, the current study was targeted to evaluate the effects of feeding frequency on growth, feed utilization and proximate composition of Bagrid catfish, and assess the effects of feeding frequency on water quality as well.

\section{MATERIALS AND METHODS}

\section{Experimental fish}

Juvenile Bagrid catfish (Chrysichthys nigrodigitatus), with an average weight of $24.35 \mathrm{~g}$, was collected from the Volta Lake. Specimens were transported to S-Hoint Fish Farm. Fish were acclimatized for one month prior to the experiment.

\section{Experimental Design}

Acclimatized fish were randomly distributed into twelve tanks (four groups and three triplicates). Each tank $(3 \mathrm{~m} \times 1 \mathrm{~m} \times 1 \mathrm{~m})$ was stocked with 30 juveniles of Bagrid catfish. 


\section{Feed and feeding}

Fish were fed commercial diet purchased from Aller Aqua in Ghana. The proximate composition of the experimental diet is shown in Table (1).

Table 1. Proximate composition of experimental diet

\begin{tabular}{l|l}
\hline Proximate composition (\% dry matter) & Percentage (\%) \\
\hline Protein & 58.0 \\
\hline Lipid & 17.0 \\
\hline Ash & 12.2 \\
\hline Nitrogen free extract & 6.1 \\
\hline Fiber & 0.7 \\
\hline Phosphorus & 1.4 \\
\hline Sodium & 0.9 \\
\hline Calcium & 2.5 \\
\hline
\end{tabular}

Four feeding frequencies $\left(1,2,3\right.$, and 4 times.day $\left.^{-1}\right)$ were adopted in this study. Uneaten feed from the previous feeding was collected from trays and weighed. Table (2) shows the feeding frequency and the schedule employed in each treatment. Fish were fed $5 \%$ of their body weight for eight (8) weeks.

Table 2. Daily feeding frequency and time for juvenile Bagrid catfish during the feeding trial

\begin{tabular}{l|r|r|r|r|r|r|r|r|r|r}
\hline \multirow{2}{*}{$\begin{array}{l}\text { Feeding frequency } \\
\text { (times day) }\end{array}$} & \multicolumn{7}{|c}{ Feeding time } \\
\hline $\mathbf{1}$ & $7: 00$ & $8: 00$ & $9: 30$ & $10: 00$ & $10: 30$ & $12: 00$ & $13: 00$ & $14: 00$ & $15: 00$ & $16: 00$ \\
\hline $\mathbf{2}$ & & & & & $\checkmark$ & & & & \\
\hline $\mathbf{3}$ & & & $\checkmark$ & & & & & & $\checkmark$ \\
\hline $\mathbf{4}$ & & $\checkmark$ & & & $\checkmark$ & & & & $\checkmark$ \\
\hline
\end{tabular}

\section{Sample collection}

At the end of the feeding trial, all surviving fishes were counted, and the weight and length (total and fork length) were measured in grams $(\mathrm{g})$ and $(\mathrm{cm})$, respectively in order to calculate survival rate, weight gain and specific growth rate. The muscle and whole body of fish were selected randomly for the analysis of proximate composition.

\section{Growth and feed utilization}

- The growth performance and feed utilization parameters were measured as follows:

- Weight gain $(\mathrm{WG})=$ final weight $(\mathrm{g})$ - initial weight $(\mathrm{g})$

- Specific growth rate $(\mathrm{SGR})(\%)=(\ln$ final weight $(\mathrm{g})-\ln$ initial weight $(\mathrm{g})) / \mathrm{T} \times$ 100 , where $\mathrm{T}$ is the number of experimental (feeding) days

- Condition factor $(\mathrm{K})=\left[\right.$ body weight $/$ standard length $\left.{ }^{3}\right]$. Standard length is measured in $\mathrm{cm}$.

- Feed intake (FI) is the total feed consumed (g) during the 56 day- trial.

- Feed conversion ratio $(\mathrm{FCR})=$ feed intake $(\mathrm{g}) /$ weight gain $(\mathrm{g})$ 
- Protein efficiency ratio $(\mathrm{PER})=$ wet weight gain $(\mathrm{g}) /$ protein intake $(\mathrm{g})$

- \% Weight gain $(\% \mathrm{WG})=100 \mathrm{X}$ [final weight $(\mathrm{g})-$ initial weight $(\mathrm{g})] /$ initial weight

\section{Water quality analysis}

Testo- 110 (United Kingdom) was used to measure temperature on daily basis at 08:00 am by inserting the metallic and sensitive probe into the water at about $20-30 \mathrm{~cm}$ from the surface. Crison OXI 45 (Spain) model oxygen meter was used to measure the dissolved oxygen at a depth of $30 \mathrm{~cm}$. Dissolved oxygen readings were taken at six different points across the pond, and the average was calculated. Nitrate, $\mathrm{pH}$, nitrite, and ammonia were measured using the protocols of APHA (2005).

\section{Proximate composition}

Samples of the experimental fish (five fishes per tank) were sent to the Spanish Laboratory of University for Development Studies, Nyankpala Campus for analysis of moisture, ash, lipids and protein. The standard methods of AOAC (2003) were used as described in the study of Mehbood et al. (2017).

\section{Statistical analysis}

Data obtained was statistically analyzed using Graph Pad Prism (V.5.03). The data were presented in graphs and tables using the mean \pm standard error of the mean (SEM). One-way Analysis of Variance and Tukey's multiple tests were used to analyze all data to compare treatment means. Differences are considered significant at 0.05 probability level $(P<0.05)$ for all data. Correlation analysis was performed between feeding frequency, water quality and growth performance using Past 3 software.

\section{RESULTS}

\section{Effects of feeding frequency on water quality}

Table (3) shows water quality parameters measured in this study. Dissolved oxygen and ammonia were significantly influenced by feeding frequency $(P<0.05)$. On the other hand, temperature, $\mathrm{pH}$, nitrite and nitrate were not significantly affected by feeding frequency $(P>0.05)$. Temperature ranged between $29.15^{\circ} \mathrm{C}$ and $29.70^{\circ} \mathrm{C}$, with $\mathrm{pH}$ ranging between 6.93 and 7.00. Ammonia decreased with feeding frequencies, whereas nitrate increased with increasing feeding frequencies. Feeding Bagrid catfish once and twice a day recorded significantly higher dissolved oxygen compared to those fed three and four times a day. Dissolved oxygen ranged between $4.22 \pm 0.09 \mathrm{mg} . \mathrm{l}^{-1}$ and $5.25 \pm 0.07 \mathrm{mg}$. $\mathrm{l}^{-1}$. The highest ammonia content was observed in group fed 4 times a day and was significantly higher than all the other treatments $(P<0.05)$. 
Table 3. Water quality parameters during the rearing of Chrysichthys nigrodigitatus juveniles under different feeding frequencies

\begin{tabular}{l|l|l|l|l|l}
\hline Parameter (unit) & Trt1 & Trt2 & Trt3 & Trt4 & $p$-value \\
\hline Temperature $\left({ }^{\circ} \mathrm{C}\right)$ & $\begin{array}{l}29.70 \\
0.24\end{array}$ & $29.15 \pm 0.26$ & $29.47 \pm 0.25$ & $29.28 \pm 0.24$ & 0.4695 \\
\hline $\mathrm{pH}(\mathrm{pH}$ unit) & $6.93 \pm 0.04$ & $6.96 \pm 0.03$ & $7.00 \pm 0.05$ & $7.11 \pm 0.12$ & 0.3208 \\
\hline Dissolved oxygen $\left(\mathrm{mg} .^{-1}\right)$ & $5.25 \pm 0.07^{\mathrm{b}}$ & $5.05 \pm 0.05^{\mathrm{b}}$ & $4.37 \pm 0.04^{\mathrm{a}}$ & $4.22 \pm 0.09^{\mathrm{a}}$ & 0.0451 \\
\hline Ammonia (mg. $\left.\mathrm{l}^{-1}\right)$ & $0.27 \pm 0.04^{\mathrm{a}}$ & $0.26 \pm 0.04^{\mathrm{a}}$ & $0.30 \pm 0.03^{\mathrm{a}}$ & $0.43 \pm 0.12^{\mathrm{b}}$ & 0.0493 \\
\hline Nitrite $\left(\mathrm{mg} . \mathrm{l}^{-1}\right)$ & $0.25 \pm 0.01$ & $0.25 \pm 0.01$ & $0.26 \pm 0.02$ & $0.25 \pm 0.01$ & 0.5723 \\
\hline Nitrate $\left(\mathrm{mg} . \mathrm{l}^{-1}\right)$ & $5.02 \pm 0.15$ & $5.07 \pm 0.21$ & $5.11 \pm 0.08$ & $5.14 \pm 0.19$ & 0.6179 \\
\hline
\end{tabular}

Values are means \pm SEM. $(\mathrm{n}=3)$. Means in the same column with different superscripts are significantly different $(P<0.05)$. Trt1 $=$ frequency $1(12$ noon $) ; \operatorname{Trt} 2=$ frequency $2(10: 00 \mathrm{am} \& 16: 00 \mathrm{pm}) ; \operatorname{Trt} 3=$ frequency $3(8: 00 \mathrm{am}, 12$ noon \& 16:00 pm) and Trt4 = frequency $4(8: 00 \mathrm{am}, 10: 30 \mathrm{am}, 13: 00 \mathrm{pm} \&$ 15:00 $\mathrm{pm})$.

\section{Effects of feeding frequencies on growth performance}

The effects of feeding frequencies on growth performance after eight weeks of feeding are presented in Table (4). No significant difference was detected in final length $(P>0.05)$. However, a significant difference was marked amongst treatments with respect to final weight, weight gain and condition factor. The Trt 2 recorded the highest final weight, weight gain and condition factor. Condition factor ranged between $0.78 \pm 0.01$ and $0.96 \pm 0.05$, whilst weight gain and final weight ranged between $29.47 \pm 2.31$ and $41.90 \pm 2.75$, and $54.00 \pm 2.33$ and $57.23 \pm 2.86$, respectively. Specific growth rate was significantly higher in fish fed twice a day (Trt2) compared to fish fed Trt1, Trt3 and Trt4 $(P<0.05)$. The SGR ranged between $3.90 \pm 0.04$ and $4.13 \pm 0.03$.

Table 4. Growth performance of Bagrid catfish juveniles subjected to different feeding frequencies

\begin{tabular}{|c|c|c|c|c|c|c|c|}
\hline Treatment & IL (cm) & FL $(\mathbf{c m})$ & IW (g) & FW (g) & WG (g) & $\mathbf{C F}$ & SGR (\%) \\
\hline Trt 1 & $\begin{array}{ll}14.72 & \pm \\
1.59 & \\
\end{array}$ & $19.10 \pm 0.29$ & $26.17 \pm 0.89$ & $57.23 \pm 2.86^{\mathrm{a}}$ & $31.07 \pm 3.58^{\mathrm{a}}$ & $0.81 \pm 0.01^{\mathrm{a}}$ & $3.95 \pm 0.04^{\mathrm{a}}$ \\
\hline Trt 2 & $\begin{array}{l}14.26 \\
2.35\end{array}$ & $19.29 \pm 0.31$ & $25.30 \pm 0.85$ & $67.20 \pm 2.07^{b}$ & $41.90 \pm 2.75^{b}$ & $0.96 \pm 0.05^{b}$ & $4.13 \pm 0.03^{b}$ \\
\hline Trt 3 & $\begin{array}{l}14.67 \\
4.43 \\
\end{array}$ & $18.98 \pm 0.25$ & $23.13 \pm 1.18$ & $54.00 \pm 2.33^{\mathrm{a}}$ & $30.87 \pm 2.55^{\mathrm{a}}$ & $0.78 \pm 0.02^{\mathrm{a}}$ & $3.90 \pm 0.04^{\mathrm{a}}$ \\
\hline Trt 4 & $\begin{array}{l}14.11 \\
3.23 \\
\end{array}$ & $19.03 \pm 0.21$ & $24.63 \pm 1.03$ & $54.10 \pm 1.99^{a}$ & $29.47 \pm 2.31^{\mathrm{a}}$ & $0.78 \pm 0.01^{\mathrm{a}}$ & $3.91 \pm 0.07^{\mathrm{a}}$ \\
\hline$p$-value & 0.7535 & 0.8569 & 0.1845 & 0.0002 & 0.0007 & $<0.0001$ & 0.0001 \\
\hline
\end{tabular}

Values are means \pm SEM. $(\mathrm{n}=3)$. Means in the same column with different superscripts are significantly different $(P<0.05)$. IL; Initial length, FL; Final length, IW; initial weight, FW; final weight, WG; weight gain, $\mathrm{CF}$; condition factor, SGR; specific growth rate. 


\section{Effects of feeding frequency on hepatosomatic index, viserasomatic index, and feed utilization}

The effects of feeding frequency on hepatosomatic index, viserasomatic index and feed utilization are shown in Table (5). Feed conversion ratio (FCR) was significantly influenced by the feeding frequencies $(\mathrm{p}<0.05)$. Fish fed twice a day $(\operatorname{Trt} 2)$ had FCR significantly lower than the other three groups. A significant difference was noted in protein efficiency ratio (PER) $(\mathrm{p}<0.05)$. Fish fed Trt3 and Trt4 recorded the least PER and was significantly lower than fish fed Trt1 and Trt2. The highest PER (0.87) was recorded in fish fed three times a day (Trt3), while fish fed twice a day (Trt2) recorded the highest PER (1.72). Trt2 recorded the highest feed intake (42.01), followed by Trt1 (37.79), Trt3(35.73) and Trt4 (32.54), respectively. Feed intake of fish fed twice a day was significantly higher than all other treatments $(\mathrm{p}<0.05)$. There was no significant difference among treatments, with respect to the hepatosomatic index. Fish fed diet Trt4 recorded the highest hepatosomatic index of $1.85 \pm 0.15$, whereas fish fed diet Trt3 recorded the least hepatosomatic index of 1.76 \pm 0.99 . Viscerasomatic index was indifferent irrespective of the feeding frequency. Viscerasomatic index for fish fed diets Trt1, Trt2 and Trt3 were 5.52 $\pm 0.30,5.25 \pm 0.80$ and $5.16 \pm 0.25$, respectively, while fish fed diets T4 recorded viscerasomatic index of 5.34 \pm 0.45 .

Table 5. Effects of feeding frequency on hepatosomatic index, viserasomatic index and feed utilization

\begin{tabular}{|c|c|c|c|c|c|}
\hline Parameters & Trt1 & Trt2 & Trt3 & Trt4 & p-value \\
\hline PER & $1.41 \pm 0.13^{b}$ & $1.72 \pm 0.08^{b}$ & $0.87 \pm 0.06^{\mathrm{a}}$ & $0.92 \pm 0.06^{\mathrm{a}}$ & $<0.0001$ \\
\hline FI & $37.79 \pm 2.43^{b}$ & $\begin{array}{ll}42.01 & \pm \\
4.17^{\mathrm{c}} & \\
\end{array}$ & $\begin{array}{ll}35.73 & \pm \\
3.15^{\mathrm{b}} & \\
\end{array}$ & $\begin{array}{ll}32.54 & \pm \\
2.25^{\mathrm{a}} & \\
\end{array}$ & $<0.0001$ \\
\hline FCR & $1.50 \pm 0.12^{\mathrm{c}}$ & $1.07 \pm 0.05^{\mathrm{a}}$ & $1.39 \pm 0.12^{\mathrm{ab}}$ & $1.27 \pm 0.08^{\mathrm{ab}}$ & 0.0283 \\
\hline VSI & $5.52 \pm 0.30$ & $5.25 \pm 0.80$ & $5.16 \pm 0.25$ & $5.34 \pm 0.45$ & 0.4271 \\
\hline HIS & $1.83 \pm 0.19$ & $1.80 \pm 0.29$ & $1.76 \pm 0.99$ & $1.85 \pm 0.15$ & 0.0725 \\
\hline
\end{tabular}

Values are means \pm SEM. $(\mathrm{n}=3)$. Means in the same column with different superscripts are significantly different $(P<0.05)$. PER; Protein efficiency ratio, FI; Feed intake, FCR; Feed conversion ratio, VSI; Viscerasomatic index, HIS; Hepatosomatic index.

\section{Proximate composition}

The effect of feeding frequency on proximate composition is shown in Table (6). No significant difference was determined in protein, moisture, lipid and ash $(P>0.05)$. The highest protein $(46.29 \pm 4.15)$ and moisture $(75.94 \pm 3.34)$ were observed in fish fed diets Trt4 and Trt3. A reduction was observed in lipid content as feeding frequency increased. Fish fed diet Trt1 recorded lipid content of $11.98 \pm 1.54$. Ash content ranged between $15.14 \pm 0.45$ and $15.93 \pm 0.77$. 
Table 6. Effects of feeding frequency on proximate composition of Bagrid catfish

\begin{tabular}{l|l|l|l|l|l}
\hline Parameter & Trt1 & Trt2 & Trt3 & Trt4 & $\boldsymbol{p}$-value \\
\hline Protein $(\%)$ & $44.94 \pm 3.41$ & $45.23 \pm 2.55$ & $45.90 \pm 3.12$ & $46.29 \pm 4.15$ & 0.5241 \\
\hline Moisture (\%) & $75.86 \pm 2.25$ & $75.06 \pm 4.01$ & $75.94 \pm 3.34$ & $75.59 \pm 1.79$ & 0.7592 \\
\hline Lipid (\%) & $11.98 \pm 1.54$ & $11.69 \pm 1.35$ & $10.70 \pm 2.23$ & $10.15 \pm 1.27$ & 0.6219 \\
\hline Ash (\%) & $15.93 \pm 0.77$ & $15.52 \pm 0.98$ & $15.14 \pm 0.45$ & $15.87 \pm 0.68$ & 0.7371 \\
\hline
\end{tabular}

Values are means \pm SEM. $(\mathrm{n}=3)$. Means in the same column with different superscripts are significantly different $(P<0.05)$.

\section{Correlation between feeding frequency, water quality and growth performance}

Correlation between feeding frequency, water quality and growth performance are shown in Fig. (1). Feeding frequency correlated positively with $\mathrm{pH}(0.049)$ and nitrate (0.006), while a negative correlation was detected with dissolved oxygen (0.034). On the other hand, there was no significant correlation between feeding frequency and other water quality parameters, such as nitrite (0.741), ammonia (0.145) and temperature (0.492).

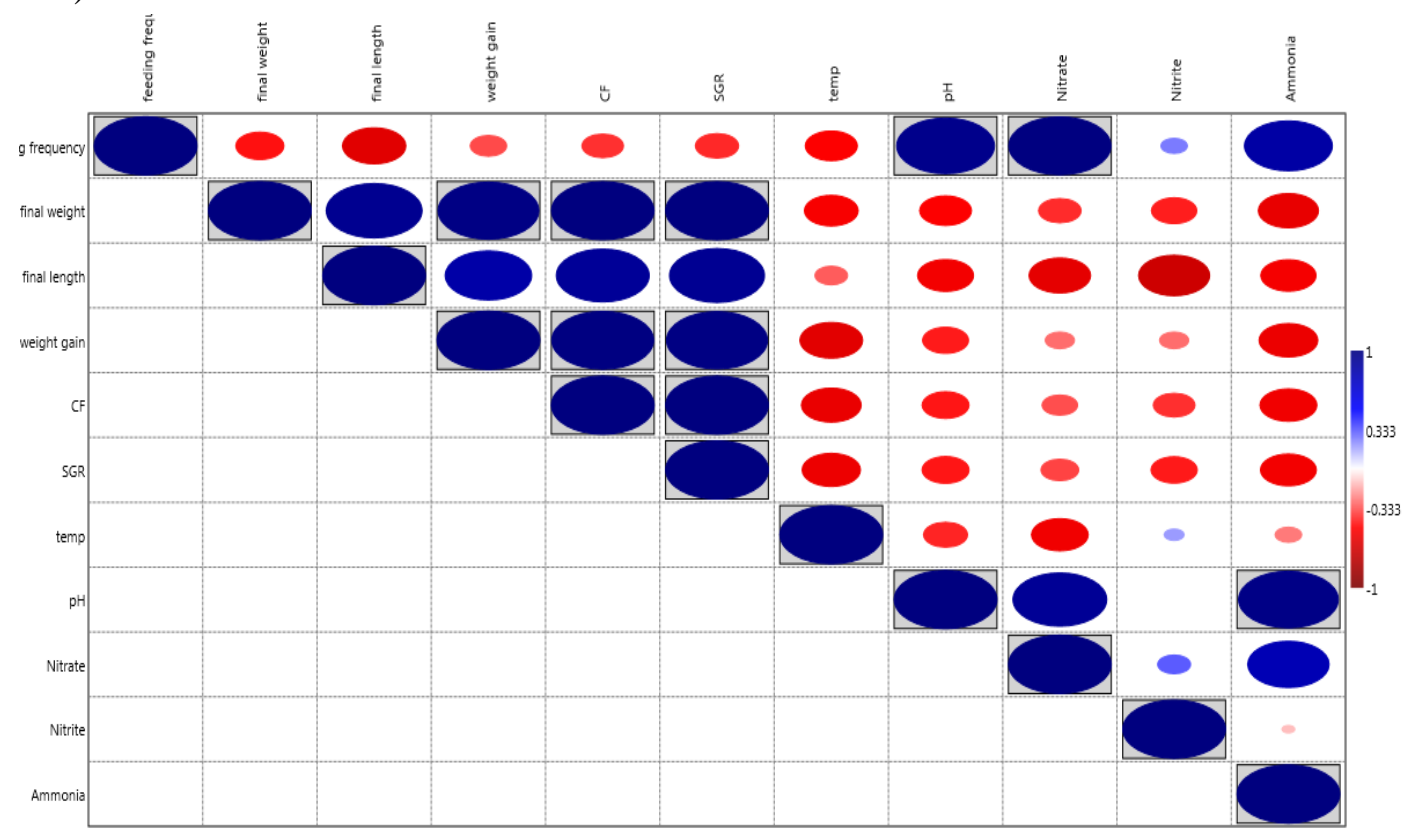

Fig. 1. Relationship between feeding frequencies, water quality and growth performance of Bagrid catfish. Red colors correlate negatively, while blue colors correlate positively. Boxed symbols correlate significantly. The bigger the symbols, the stronger the correlation.

\section{Variations in size and specific growth rate}

Fig. (2) shows the variation coefficient (\%) for final weight, weight gain and specific growth rate. Variations in specific growth rate for fish fed diets Trt1 and Trt2 were $6.30 \%$ and $4.06 \%$, respectively, whereas fish fed Trt3 and Trt4 recorded variations of $5.98 \%$ and $5.12 \%$, respectively.

For the final weight, there was $27.39 \%, 16.89 \%$ and $23.71 \%$ variance among fishes in Trt1, Trt2 and Trt3, respectively; however, fishes in Trt4 varied at $20.23 \%$. 
The highest variation in specific growth rate of $6.30 \%$ was recorded in fishes in Trt1, followed by fishes in Trt3, Trt4 and Trt2, with variations of 5.98\%, 5.12\% and $4.06 \%$, respectively.

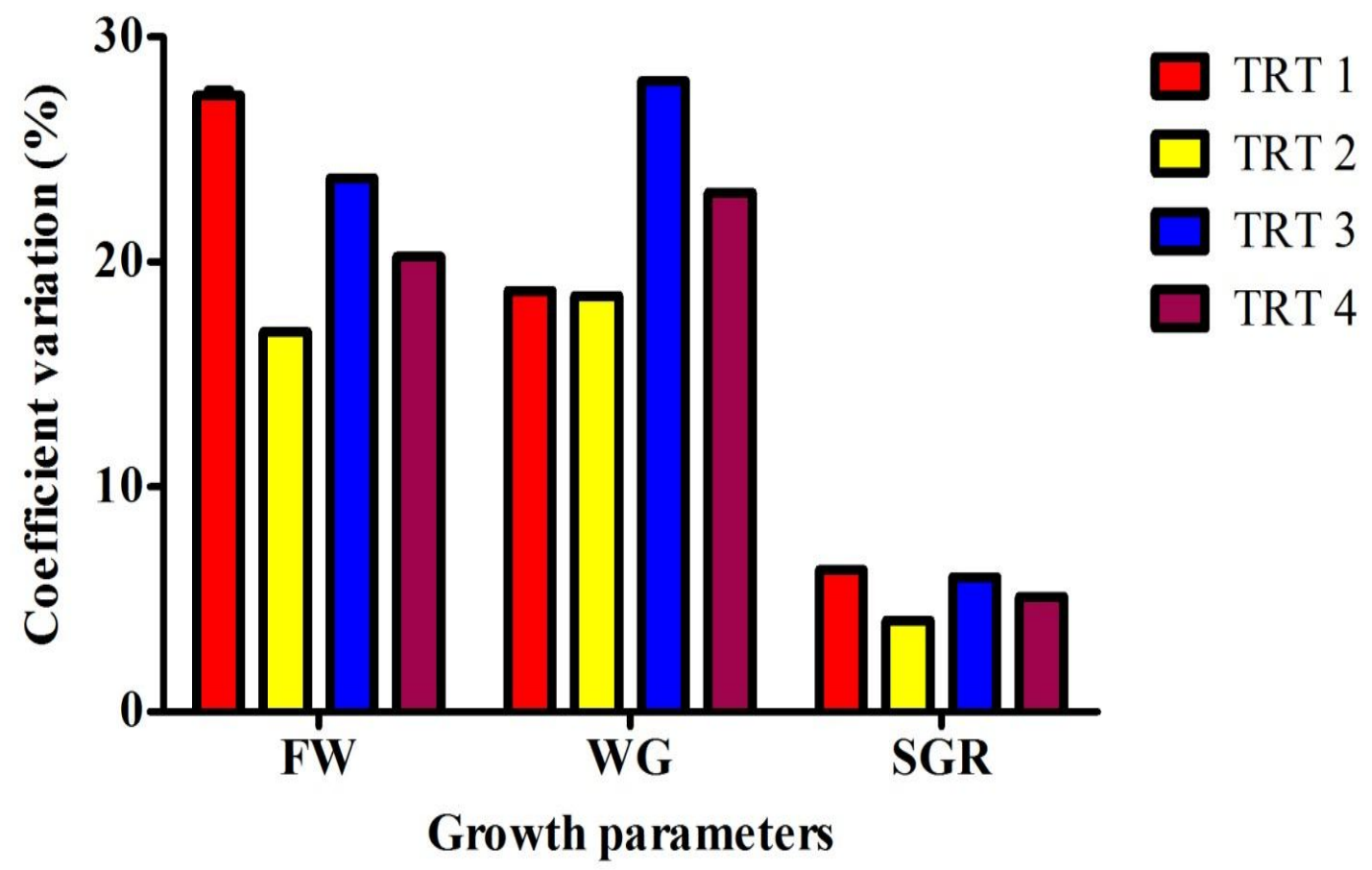

Fig. 2. Coefficient of variation (mean $\pm S E, n=3$ ) of final weight, weight gain and specific growth rate of Bagrid catfish fed at different feeding frequencies for 56 days

\section{DISCUSSION}

Feeding frequency had significant influence on growth performance of Bagrid catfish. Feeding Bagrid catfish twice a day resulted in the best growth performance. This result coincides with that of Ashley-dejo et al. (2014). Similarly, Marimuthu et al. (2010) documented that, feeding $C$. gariepinus twice a day enhanced the growth performance even that it was not significantly different from other treatments. In addition, the present result concurs with that of Dwyer et al. (2002) who documented that, feeding yellow tail flounder with two meals per day enhanced the growth performance. Moreover, this study agrees with previous report of Karen et al. (2002) which postulated that, feeding juvenile yellow flounder for two times a day improved the growth performance significantly. It is worthy to mention that, feeding Bagrid catfish four times a day recorded the least growth performance. This could be due to three reasons. First; energy expenditure may increase as a result of increased swimming activity arising from feeding throughout long periods of the day (Johansen \&Jobling, 1998). Secondly, feeding at shorter intervals results in food passing through the digestive 
tract more quickly leading to less effective digestion (Liu \& Liao, 1999). Thirdly, the poor growth recorded in fish fed four times a day could be a result of the reduction in the absorption efficiency resulting from gastric overload due to feeding at a relatively short intervals than the time required for the fish appetite to return (Riche et al., 2004).

Notably, a reduction in growth performance was observed when Bagrid catfish was fed three and four times a day. This finding mimics with results in previous studies (Lee et al. 2000; Dwyer et al. 2002; Aydın et al. 2011; Xie et al. 2011; Küçük et al., 2014; Mizanur \& Bai, 2014; Maran, 2015; Sung-Yong \& Venmathi, 2015), in which a reduction was recorded in growth after a certain feeding frequency. The lower growth rate recorded in fish fed three and four times a day could be attributed to oxygen consumption (Guinea \& Fenandez, 1997) and an increased foraging activity (Johnsen \& Jobling, 1998).

Feed intake increases to a certain limit as feeding frequency increases. Remarkably, feed intake varies among fish species. Similarly, the effects of feeding frequency on feed intake vary among fish species (Daudpota et al., 2016). This study revealed an increase in feed intake up to a two times daily feeding; however, a decline was observed when feeding frequency was further increased to three and four times a day. The present study showed significant difference in feed intake. This result corroborates with that of Aderolu et al. (2009) who reported that, feeding frequency had significant influence on feed intake. Moreover, Guo et al. (2018) reported a significant variation in feed intake when the juveniles of Dolly Varden char, Salvelinus malma were fed one to six times a day.

Feed intake is related to the capacity of the stomach; the rate at which feed is digested as well as how fast food is evacuated. The suitability of feeding frequency is therefore affected by the intervals between feeding (Mihelakakis et al., 2001). Fish fed twice a day (Trt2) recorded the best growth performance with feed intake and corresponded with the best growth performance. This implies that feeding Bagrid catfish twice a day at an interval of six hours could enhance growth.

Feed conversion ratio is an important parameter used to assess the ability of fish to convert one unit of feed to a corresponding body weight. It has been documented that the smaller the feed conversion ratio, the better the growth. Sung-Yong and Venmathi (2015) reported that, feeding juvenile rock bream (Oplegnathus fasciatus) at four different feeding frequencies had no significant alteration in the feed conversion ratio. Furthermore, Costa-Bomfim (2014) did not observe significant alteration in feed conversion ratio when cobia was fed at different frequencies. The present study contradicts with the above report since feed conversion ratio was significantly altered by the four feeding frequencies. Similarly, Busti et al. (2019) documented a non-significant difference in feed conversion ratio in feed conversion ratio of gilthead sea bream (Sparus aurata) fed at different frequencies. Moreover, the present study reported feed conversion ratio which ranged from $1.27 \pm 0.08$ to $1.50 \pm 0.12$, forming a slightly lower value than that 
of Eyo Ekanem (2011) who determined ranges between 1.55 \pm 0.04 and $1.78 \pm 0.09$. The significant difference observed in feed conversion ratio indicates that the efficiency of feed utilization and feed conversion was influenced by the feed frequency, and that Bagrid catfish under different feeding frequency utilize feed differently.

The ability to easily and quickly determine the condition factor, the hepatosomatic and the viserasomatic indexes, which are often used to evaluate nutritional status of fish, gives an indication of the physiological state of fish. The size of the liver of fish positively correlates with the nutritional status of fish, hence bigger hepatosomatic index indicates good health. There was no significant difference among treatments with respect to hepatosomatic index. This is comparable to the study of Tian et al. (2015) when juvenile blunt snout bream (Megalobrama amblycephala) fed at six different feeding frequencies did not affect hepatosomatic index significantly. This implies that feeding at different frequencies up to four times a day does not compromise the health of Bagrid catfish.

The current study reported an increase in whole body protein content as feeding frequency increased. This finding agrees with the results of Zhou et al. (2003) and Lee and Pham (2010). A decrease was observed in the whole body lipid as feeding frequency increased. This contradicts with the results of the study of Lee et al. (2000) on juvenile Korean rockfish, Tian et al. (2015) on blunt snout bream juvenile and Wu et al. (2015) on golden pompano. This indicates that increasing the feeding frequency could degrade body lipid content of Bagrid catfish.

The growth of fish is partly regulated by the physico-chemical parameters of water (Bassey \& Ajah, 2010). A significant decrease was identified in the dissolved oxygen as feeding frequency increased. Furthermore, a significant increase was notified in ammonia content as feeding frequency increased. Even though, the parameters of water quality were within the acceptable ranges for rearing of catfishes, the results give an indication that excessive increase in feeding frequency could reduce dissolved oxygen and increase ammonia which could have negative effects on fish growth. The results coincide with that of Okomoda et al. (2019) who reported a decrease in dissolved oxygen content when the feeding frequency was increased during the culture of Clarias gariepinus. Moreover, the present result is in accordance with the study of Marimuthu $\boldsymbol{e t}$ al. (2010) who noted a significant difference in dissolved oxygen when African catfish (C. gariepinus) were fed once per day, twice per day, once on an alternate day and twice on an alternate day.

Eminently, fish are mostly sold based on weight. Uniform sized fish yield better price as compared to non-uniform sized fish. It is necessary to reduce variation in size during production (Biswas et al., 2010). Hierarchy effects and/ or competition for food are the two main causes of coefficient variation in fish (Küçük et al., 2014). Some researchers have studied the effects of feeding frequency on coefficient variation. Oh $\boldsymbol{e t}$ al. (2019) reported no significant difference in coefficient variation for growth among 
individuals when juvenile short barbeled velvetchin Hapalogenys nigripinnis were fed one to four times a day. Similarly, Xie et al. (2011) reported no significant variation in the case of yellow croaker. Furthermore, Küçük et al. (2014) postulaed no coefficient variation in Brazilian sardine Sardinella brasiliensis and flounder fed at different frequencies. The result of the present study confirms their reports. Contrary to our results, there was significant difference in inter-individual size when Sung-Yong and Venmathi (2015) fed juvenile rock bream at different feeding frequencies.

Baloi et al. (2014) recorded coefficient variation of final body weight ranging from $19.64 \pm 0.86$ to $20.96 \pm 1.67$ when juvenile Brazilian sardine, Sardinella brasiliensis (Steindacher, 1879) were fed one to six times a day. Coefficient of variation for final weight recorded in the present study falls in line with that of Baloi et al. (2014), even though it was higher than the report of Sung-Yong and Venmathi (2015) where juvenile rock bream (Oplegnathus fasciatus) were fed one to four meals a day.

\section{CONCLUSION}

In conclusion, the present study indicates that feeding frequency affects growth performance and feed utilization in the culture of Bagrid catfish. Additionally, it could be concluded that higher levels of feeding frequency could deteriorate water quality by decreasing the dissolved oxygen content and increasing the levels of ammonia in ponds.

\section{REFERENCES}

Aderolu, A. Z.; Seriki, B. M.; Apatira, A. L. and Ajaegbo, C. U. (2010). Effects of feeding frequency on growth, feed efficiency and economic viability of rearing African catfish (Clarias gariepinus, Burchell 1822) fingerlings and juveniles. African Journal of Food Science, 4(5): 286 - 290

Alemayehu, T.A. and Getahun, A. (2017). Effect of Feeding Frequency on Growth Performance and Survival of Nile Tilapia (Oreochromis niloticus L. 1758) in a Cage Culture System in Lake Hora-Arsedi, Ethiopia. Journal of Aquaculture Research and Development 8:479.

Ali, E-S.T.; Martı'nez-Llorens, S.; Moñino, A.V.; Cerda', M.J. and Toma's-Vida, A. (2016). Effects of weekly feeding frequency and previous ration restriction on the compensatory growth and body composition of Nile tilapia fingerlings. Egyptian Journal of Aquatic Research, 42: 357-363.

AOAC. (2003). Official methods of analysis, 17th ed. Association of Official Analytical Chemists, Washington DC, USA

APHA, (2005). Standard Methods for the Examination of Water and Waste Water. Fourteenth Edition, American Public Health Association (APHA), Washington DC, USA. Ashley-dejo, S.S.; Olaoye, O.J.; Adelaja, O.A. and Abdulraheem, I. (2014). Effects of feeding levels on growth performance, feed utilization and body 
composition of African catfish (Clarias gariepinus, Burchell1822). Int. J. Biol. and Biol. Sci. 3(2): 012-016.

Aydın, I.; Kuc suk, E.; Sahin, T. and Kolotoglu, L. (2011). The effect of feeding frequency and feeding rate on growth performance of juvenile Black Sea Turbot (Psetta maxima Linneaus, 1758). J Fishscicom 5:35-42

Baloi, M.; De Carvalho, C.; Sterzelecki, F.; Passini, G. and Cerqueira, V.R. (2014). Effects of feeding frequency on growth, feed efficiency and body composition of juveniles Brazilian sardine, Sardinella brasiliensis (Steindacher 1879). Aquaculture Research, 47:554-560.

Bassey, A.U. and Ajah, P.O. (2010). Effect of three Feeding Regimes on Growth, Condition Factor and Food Conversion rate of Pond Cultured Parachanna obscura (Gunther, 1861) (Channidae) in Calabar, Nigeria. Turkish Journal of Fisheries and Aquatic Sciences 10: 195-202

Biswas, G.; Thirunavukkarasu, A.R.; Sundaray, J.K. and Kailasam, M. (2010). Optimization of feeding frequency of Asian seabass (Lates calcarifer) fry reared in net cages under brackish water environment. Aquaculture 305(1-4):26-31

Busti, S.; Bonaldo, A.; Dondi, F.; Cavallini, D.;Yúfera, M.; Gilannejad, N.; Moyano, F.J.; Gatta, P.P. and Parma, L. 2020. Effects of different feeding frequencies on growth, feed utilisation, digestive enzyme activities and plasma biochemistry of gilthead sea bream (Sparus aurata) fed with different fishmeal and fish oil dietary levels. Aquaculture, 529:735616.

Costa-Bomfim, C.N.; Pessoa, W.V.N.; Oliveira, R.L.M.; Farias, J. L.; Domingues, E. C.; Hamilton, S. and Cavalli, R.O. (2014). The effect of feeding frequency on growth performance of juvenile cobia, Rachycentron canadum (Linnaeus, 1766). Journal of Applied Ichthyology. 30:135-139.

Daudpota, A.M.; Abbas, G.; Kalhoro, I.B.; Shah, S.S.A.; Kalhoro, H.;Hafeez-urRehman, M. and Ghaffar, A. (2016). Effect of Feeding Frequency on Growth Performance, Feed Utilization and Body Composition of Juvenile Nile Tilapia, Oreochromis niloticus (L.) Reared in Low Salinity Water. Pakistan Journal of Zoology 48(1): 171-177.

Dias, J. D.; Takahashi, E.M.; Santana, N. F. and Bonecker C. C. (2011). Impact of fish cage-culture on the community structure of zooplankton in a tropical reservoir. Iheringia Série, Zoologia Porto Alegre, 101(1-2):75-84.

Dwyer, K.S.; Brown, J.A.; Parrish, C. and Lall, S.P. (2002). Feeding frequency affects food consumption, feeding pattern and growth of juvenile yellowtail flounder (Limanda ferruginea). Aquaculture 213: 279-292.

Eyo, V.O. and Ekenam, A.P. (2011). Effect of feeding frequency on the growth, food utilization and survival of African catfish (Clarias gariepinus) using locally formulated diet. African Journal of Environmental Pollution and Health 9(2):11-17. 
Guinea, J. and Fernandez, F. (1997). Effect of feeding frequency, feeding levels and temperature on energy metabolism in Sparus aurata . Aquaculture 148:125-142

Guo, Z.; Cui, J.; Li, M.; Liu, H.; Zhang, M.; Meng, M.; Shi, G.; Wang, R.; He, X. and Zhao, Y. (2018). Effect of feeding frequency on growth performance, antioxidant status, immune response and resistance to hypoxia stress challenge on juvenile dolly varden char Salvelinus malma. Aquaculture 486: 197-201.

Johansen, S.J.S. and Jobling, M. (1998). The influence of feeding regime on growth and

slaughter traits of cage-reared Atlantic salmon. Aquaculture International 6 (1): 1-17

Karen, S.D.; Joseph, A.B.; Christopher, P. and Santosh, P.L. (2002). Feeding frequency affects food consumption, feeding pattern and growth of juvenile yellowtail flounder (Limanda ferruginea). Aquaculture 213: 279-292.

Küçük, E.; Aydin, İ.; Polat, H.; Eroldoğan, O.T. and Şahin, T. (2014). Effect of feeding frequency on growth, feed efficiency and nutrient utilization of juvenile flounder (Platichthys flesus Iuscus). Aquaculture International 22(2):723-732.

Lee, S.-M.; Cho, S.H. and Kim, D.-J. (2000). Effects of feeding frequency and dietary energy level on growth and body composition of juvenile flounder, Paralichthys olivaceus (Temminck and Schlegel). Aquaculture Research 31: 917-921.

Lee, S-M. and Pham, M.A. (2010). Effects of feeding frequency and feed type on the growth, feed utilization and body composition of juvenile olive flounder, Paralichthys olivaceus. Aquaculture Research 41: e166-e171

Lee, S-M.; Hwang, U.G. and Cho, S.H. (2000). Effects of feeding frequency and dietary moisture content on growth, body composition and gastric evacuation of juvenile Korean rockfish (Sebastes schlegeli). Aquaculture 187: 399-409.

Liu, F.G. and Liao, I.C. (1999). Effect of feeding regimen on the food consumption, growth and body composition in hybrid striped bass Morone saxitilis $\times$ M. chrysops. Fish. Sci.

(4): 513-519.

Marimuthu, K.; Cheen, A.C.; Muralikrishnan, S. and Kumar, D. (2010). Effect of different feeding frequency on the growth and survival of African catfish (Clarias gariepinus) fingerlings. Adv. Environ. Biol. pp.187 -194.

Mehbood, A.; Khan, N.; Atiq, U.; Iqbal, K.J.; Tayyab, R.; Batool, S.S.; Batool, H.S.; Amjad, S. \& Tanveer, M. (2017). Effect of fenugreek as a feed additive on the growth, body composition and apparent nutrients digestibility of striped catfish Pangasius hypophthalmus fry. Pakistan J. Zool., 49: 2037-2042.

Mihelakakis, A.; Yoshimatsu, T.T. and Tsolkas, C. (2001). Effect of feeding frequency on growth, feed efficiency, and body composition of common Pandora. Aquaculture International 9:197-204. 
Mizanur, R.M and Bai S.C. (2014). The optimum feeding frequency in growing Korean rockfish (Sebastes schlegeli) rearing at the temperature of $15{ }^{\circ} \mathrm{C}$ and $19{ }^{\circ} \mathrm{C}$. Asian Australas J Anim Sci 27 (9):1319:1327

Ng, W.K.; Lu, K.S.; Hashim, R. and Ali, A. (2000). Effects of feeding rate on growth feed utilization and body composition of a tropical bagridae catfish. Aquaculture International 8: 19-29.

Okeke, J.J.; Otikpa, C.A.; Okeke, P.A.; Ezeonyejiaku, D.C.; Okoye, C.O.; Arazu, V.N.; Ibemenuga, K.N. and Nwosu, M.C.A. (2016). comparative study of the effect of feeding frequency on growth and feed utilization of Clarias Gariepinus fed on the commercial feed- Coppens. Scholarly Journal of Agricultural Science 6(7): 216-220

Okomoda, V.T.; Aminem, W.; Hassan, A. and Martins, C.O. (2019). Effects of feeding frequency on fry and fingerlings of African catfish, Clarias gariepinus. Aquaculture 511: 734232

Riche, M.; Haley, D.I.; Oetker, M.; Garbrecht, S. and Garling, D.L. (2004). Effect of feeding frequency on gastric evacuation and the return of appetite in tilapia Oreochromis niloticus (L.). Aquaculture 234: 657-673

Riche, M.; Oetker, M.; Haley, D.I.; Smith, T. and Garling, D.L. (2004). Effect of feeding frequency on consumption, growth, and efficiency in juvenile tilapia (Oreochromis niloticus) The Israeli Journal of Aquaculture -Bamidgeh 56(4): 247-255.

Silva C.R.; Gomes L.C. and Brandão F.R.( 2007). Effect of feeding rate and frequency on tambaqui (Colossoma macropomum) growth, production and feeding costs during the first growth phase in cages. Aquaculture 264:135-139

Sung-Yong, O. and Venmathi, M.B.A. (2015). Feeding frequency influences growth, feed consumption and body composition of juvenile rock bream (Oplegnathus fasciatus). Aquaculture International 23(1):175-184.

Sung-Yong, O.; Venmathi, B.A. and Park, J.W. (2019). Optimum feeding frequency for juvenile short barbeled velvetchin Hapalogenys nigripinnis reared in floating sea cages. Fisheries Science 85(4): 379-385.

Thongprajukaew, K.; Kovitvadhi, S.; Kovitvadhi, U. and Preprame, P. (2017). Effects of feeding frequency on growth performance and digestive enzyme activity of sex-reversed Nile tilapia, Oreochromis niloticus (Linnaeus, 1758). Agriculture and Natural Resources 51:292-298

Tiamiyu, L.O.; Okomoda, V.T. and Agbo, H.E. (2018). The effect of different feeding rates and restriction on the growth performance of Clarias gariepinus. Iranian Journal of Fisheries Science 17 (4): 840-847

Tian, H.Y.; Zhang, D.D.; Li, X.F.; Zhang, C.N.; Qian, Y. and Liu, W.B. (2015). Optimum feeding frequency of juvenile blunt snout bream Megalobrama amblycephala. Aquaculture, 437: 60-66. 
Villarroel, M.; Alavriño, J.M.R and López-Luna, J. (2011). Effect of feeding frequency and one day fasting on tilapia (Oreochromis niloticus) and water quality. Israeli Jourrnal of Aquaculture-Bamidgeh 63, 609-615.

Wu, Y.; Han, H.; Qin, J. and Wang, Y. (2015). Effect of feeding frequency on growth, feed utilization, body composition and wastes output of juvenile golden pompano (Trachinotus ovatus) reared in net pens. Aquaculture Research 46: 1436-1443.

Xie, F.; Ai, Q.; Mai, K.; Xu, W. and Ma, H. (2011). The optimal feeding frequency of large yellow croaker (Pseudosciaena crocea, Richardson) larvae. Aquaculture 311 (1): $162-167$

Zhou, Z.; Cui, Y.; Xie, S.; Zhu, X.; Lei, W.; Xue M. and Yang, Y. (2003). Effect of feeding frequency on growth, feed utilization, and size variation of juvenile gibel carp (Carassius auratus gibelio). Journal of Applied Ichthyology, 19:244-249. 